DOI: 10.15393/j9.art.2013.390

\author{
Евгения Александровна Коршунова \\ кандидат филологических наук, \\ ст. преподаватель кафедры истории русской литературь, \\ Харьковский национальный университет им. В. Н. Каразина \\ (Харьков, Украина) \\ zhenyakorshunova@gmail.com
}

\title{
«ДАРИ-АНАСТАСИЯ-ОЛЬГА-ВОСКРЕСШАЯ»: К ВОПРОСУ О «ШМЕЯЕВСКОЙ ДЕВУШКЕ»
}

Аннотация: В науке о Шмелеве предпринимались неоднократно попытки выстроить типологию женских типов И. С. Шмелева. Однако писатель в своем творчестве и в переписке, одновременно с опорой на классику и в полемике с ней, на наш взгляд, выстраивает некое цельно-единство, свой неповторимый женский тип - «шмелевской девушки». Поэтому при анализе поэтики (используя сравнительно-исторический метод и метод интертекстуального анализа) нескольких произведений писателя («Неупиваемая Чаша», «Марево», «Иностранец», «Няня из Москвы», «Пути небесные») становится очевидным их тесное родство.

Галерея женских типов от Анастасии до Дариньки воплощает собой уникальный женский тип - «шмелевской девушки», той, которая встречается однажды, чистой и просветленной, женщины-принцессы, женщины-дитя, женщины-девы, наделенной иконичным мировидением, необычайно обаятельной, женственной (софийность) и в то же время сильной, преданной своим высоким духовным идеалам и способной преодолеть трагизм и испытания собственной судьбы.

Ключевые слова: тип, традиция, «шмелевская девушка», иконичность, софийность

B науке о творчестве Шмелева не раз предпринималась попытка выстроить типологию женских образов и определить их связи с русской классикой [1]. Но акцент при этом делался именно на создании некой классификации образов и их различении (религиозный, мифологически-народный тип и др.), уточнении связей с предшествующими литературными прототипами. Однако писатель в своем творчестве и в переписке, одновременно с опорой на классику и в полемике с ней, на наш взгляд, выстраивает некое цельно-единство, свой неповторимый женский тип - «шмелевской девушки». Ориентируется Шмелев, конечно же, на тургеневский тип и любимый образ Лизы Калитиной, восходящий в свою очередь к «единственно положительному женскому образу» - пушкинской 
Татьяне. Эти акценты писателя видны в любимой героине Шмелева - Дариньке, которая напоминала Лизу Калитину, и прообразе Дариньки, ее реальной предтече - Ольге Бредиус-Субботиной. Хотя Шмелев и говорит, обращаясь к ней, «ты вся из романов», но сравнивает и уподобляет только Татьяне Лариной:

Ты - необычайная, с меркой к тебе не подойду. Ты - единственная. Ты мне - Таня (БШ, 341) ${ }^{1}$.

О выделении типа «шмелевской девушки» свидетельствует как создание целой галереи женских типов, так и особое их родство, проступающее при анализе поэтики произведений писателя.

При всем разнообразии героинь Шмелев выделял общее, роднящее их между собой - русскую православную душу:

Вот, где к л а д ы - т о ! О, Россия наша! Какие девушки наши! какие!! Ду-ши-то какие! Я только чуть коснулся их... в своей работе. Правда, я много дал... Анастасию Павловну, Дари, Пашу, Катичку из «Няни»... (БШ, 433).

Женские образы приобретают для писателя особое значение: все его заветные мысли вложены в уста героинь-женщин. Кроме того, именно на женщин в прозе Шмелева (вслед за Тургеневым) возлагается миссия спасения и просвещения героев-мужчин (Даринька и Вейденгаммер, Анастасия и иконописец Илья и др.). Такая позиция объясняется особым отношением писателя к женщине - поклонением и служением ей:

Женщина живет Сердцем. <...> Она дает Мир, ergo: Мир - Ее. Мир - Она. <...> И «семя Жены сотрет главу Змия»- шире брать надо, не догматически-домыслительно: сеяемое Женой - сотрет, истлит зло (ИШ, 517-519).

В данном высказвании отчетливо виден соловьевский уклон, который был свойственен Шмелеву на протяжении всего творческого пути («Неупиваемая Чаша», «Пути небесные») и существовал не столько на идейном (писатель отделял православие от мистицизма В. Соловьева), сколько на бессознательно-творческом уровне. Сам писатель 
не осознавал своей причастности эстетике символизма, хотя использовал его приемы.

Не ограничивая роль женщины семьей и воспитанием детей, Шмелев видел в ее чуткой душевно-духовной сущности источник освящения мира и уничтожения зла. Эти представления писатель переносил на реальную жизнь, в которой ему встретилась верная и душевно прекрасная жена Ольга, вдохновившая на создание первого тома «Путей небесных», и другая Ольга, чувство к которой позволило продолжить работу над вторым томом романа. Симптоматично, что написанная с Ольги Шмелевой Даринька первых частей романа гораздо более реалистична, чем Даринька последнего тома, созданная под воздействием платонической любви к последней музе художника. Обращаясь к ней, писатель выстраивает сам единый образ «шмелевской девушки»:

Вот - Анастасия, м о г л а бы быть такой, если бы не родилась из... моего воображения. Ныне она явилась в жизни. Мне, ее Предтече-провозвестнику. Дар мне - з а в е р у, что Она е с т ь . <..> Быть может, для тебя ее искал, писал, - и вот, Тебя нашел, ж и в у ю. Дари - сложна. Но ты - сложней: тебя века лепили. Этого тебе никто не говорил, никто не скажет. Богом дано мне было - узнать тебя. Дари - твоя предтеча. <...> Ты сложная, Дари-Анастасия-Ольга-Воскресшая (курсив мой. - Е. К.) - и Победительница скорби. <..> Ты вошла, Неупиваемая Радость. Я знаю - без тебя нет жизни, воли к работе, нет вольного дыхания (БШ, 185, 241, 189).

Чтобы проследить единый метамотивный комплекс «шмелевской девушки», обратимся к репрезентации этого типа в «Неупиваемой Чаше» (1918), «Няне из Москвы» (1933) и «Путях небесных» (1950), привлекая для этого и более маргинальные для автора тексты («Марево» (1926) и роман «Иностранец» (1938)), формирующие тот же тип.

Анастасия Павловна из «Неупиваемой Чаши» становится первым образом женщины-идеала, хотя ее трудно назвать женщиной: «радостная королева-девочка», как называл героиню заезжий поэт. Детскость, присущая Анастасии, а также указание на избранность («королева»), призвана отобразить чистоту, невинность и незаурядность ее натуры. Особо 
представлен написанный штрихами портрет, воссоздающий лишь образ красоты, но детально ее не прорисовывающий. Особое внимание уделяется только глазам. Илья Шаронов отмечает в облике Анастасии «радостные глаза-звезды, несбыточные, которых ни у кого нет», «совсем розовый рот, детски полуоткрытый», «неземное лицо еще никем не написанной Мадонны». Встречи героя с Анастасией уводят его в неземное, заставляют забыть о сегодняшнем дне. Цветовая гамма с акцентом на светлых, белых тонах служит превращению госпожи в Прекрасную Даму «сошедшую с неба», воплощающую Вечную женственность, которая должна озарить жизнь мастера.

Её портрет «в овальной золоченой раме» висит в доме имения Ляпуновки, вызывая у всех трепет и очарование. Указание на то, что зрители невольно сравнивают её с неразгаданной «Моной Лизой» («на всякого глядит сразу»), является прямой отсылкой к возрожденческой традиции. После портрета внимание посетителей усадьбы привлекает деревенская церковь и расположенная возле неё могила барыни:

А эту не дозволили беспокоить. Святой жизни будто была. Старики сказывали (ССШ; I, 382).

Святой называет Анастасию Павловну столетний дьячок Каплюга, который «знает все про старину». Этими указаниями автора задано другое восприятие героини, другой образ, - иконичный, восходящий к житийной традиции. Дальнейший сюжет повести представляет собой развертывание этих двух типов изображений. Особый оттенок придает образу Анастасии трагизм ее судьбы, духовное одиночество в замужестве, переживание предательства и в то же время недюжинная сила и твердость характера, позволяющая в жизненных коллизиях не изменить себе и не потерять духовные ориентиры.

Иконичное и возрожденческое определяют те грани, между которыми выбирает Илья, работая над иконой и портретом одновременно. Несмотря на идеальность и неотмирность Анастасии, мастер желает приблизить ее к себе и овладеть этой недосягаемой звездой: 
...и губы ее помнил, ее новый рот, потерявший девственные черты и жаркий. Только один миг было (ССШ; I, 428).

Данный отрывок свидетельствует не только о соблазнах Ильи, но и об эмоциональной и страстной натуре Анастасии, также преодолевающей чувственность. Не раскрывая внутренний мир барыни, Шмелев здесь пользуется тургеневским принципом скрытого психологизма.

Написание иконы одновременно с портретом обнаруживает те «борения мастера с плотскими искушениями», которые остались незамеченными Е. Г. Рудневой $[5,30]$ и свидетельствует именно о молитвенном настрое мастера, задумавшегося о вечном. Расшифровывая направленность замысла «Неупиваемой Чаши», Е. Г. Руднева приводит высказывание Шмелева в письме Р. Г. Зиммеринг от 19 декабря 1933 г.: «Я не думал о религиозном тогда...» (т. е. в 1918 году) $[5,6]$. Двумя днями ранее Шмелев, как бы предваряя это высказывание и расшифровывая его, скажет в письме к лучшему другу И. А. Ильину:

Кто-то во мне писал. Теперь я постиг. <...> Чтобы дать великое, надо выстрадать, сломать и сжечь, перебороть вещное, плоть, даже красоту плоти. Он ее переборол - переломил «плотскую любовь», ночами ломал ее и творил «лик нездешний». Из плоти, превозмогая ее, творил - дух, высокое. Сжег себя, поборол, пронзил вещное, и за ним - узрел. И умер - оставив «Неупиваемую» - для всех. Ее не понимают, но чуют, даже дикие мужики, образ потерявшие... Вот произв<едение> искусства - для всего народа - образ, надземное, всех притягивающее: от вещного мира пошел Илья, и через вещное проник в надвещное <выделено автором> (ИШ, 429-430].

Путь от вещного к надвещному, к созданию чудотворного образа и составляет сюжет повести. Значимо, что на иконе изображается Богородица с чашей, но без Младенца. Он дописан позже, по указу архиерея. Написанная под влиянием образа Анастасии икона в данном случае приоткрывает отношение писателя к образу женщины-матери. Хотя автор упоминает о двух младенцах Анастасии, но намеренно создает другой облик - девственный. У Шмелева было какое-то чувство страха, порога, границы относительно образа жен- 
щины-матери. Рисуя своих любимиц почти девочками, Шмелев как бы «отказывал» им в возможности материнского счастья, избегая или аккуратно нивелируя развитие этой темы. Бездетны Дари, Катичка, Паша Разгуляева, Ирина Хатунцева и др. Даже в детских воспоминаниях, в «Лете Господнем», где, казалось бы, образ матери должен быть ярко прописан, он дан лишь штрихами по сравнению с личностью отца. Возможно, на это повлияли сложные отношения с матерью, строго относившейся к мальчику. Сказался и упомянутый выше соловьевский уклон.

Образ Анастасии Ляпуновой положил начало разработке этой излюбленной писателем темы. Ее развитие и динамику можно проследить на примере рассказа «Марево» и романа «Иностранец».

Героиня рассказа «Марево» Паша Разгуляева, ставшая знаменитой певицей Линой-де-Келетти из Вальпараисо, и героиня романа «Иностранец» - русская красавица-эмигрантка Ирина Хатунцева, певица с псевдонимом Таня Снежко, относятся к одному и тому же женскому типу. В изображении этих персонажей важную роль играет интертекстуальный фон.

Сказочный интертекст, вводимый Шмелевым при описании Паши, указывает на ситуацию ожидания суженого, своей судьбы. Если Анастасия Ляпунова королева, то Паша неоднократно сравнивается с царевной:

И вот, как увидал я Пашу, - сердце: царевна в сказке! Вот, Белозерск, тысячелетний. <..> И вдруг мне показалось, - сон чудесный: - в тысячелетье, в древнем! Княжна, царевна (ССШ; VII, 225).

Как отметил В. Я. Пропп, чаще всего сказочная царевна «верная невеста», которая «ждет своего суженого» $[4,298]$. Таким образом, упоминание о царевне неразрывно связано с ситуацией сватовства. Рассказ Шмелева, где главной героиней является чудесная царевна, отвечает поэтике русской сказки, в которой «именно женский образ вещей невесты господствует. <..> В ней выражается по преимуществу женственное мирочувствие» $[6,116]$. 
Сказочная ситуация обозначена не только сравнением героини с царевной, но и цветовой гаммой рассказа, хронотопом, системой персонажей. Как и в сказке, Шмелев вскользь останавливается на внешности русской красавицы, выделяя лишь наиболее часто упоминающуюся черту - золотые волосы и глаза, отражающие не только внешний, но и внутренний облик:

Ну, белое, и золотое-голубое. Вот - русская, сама Россия! Голубое платье, простое ситцевое, даже не сарпинка. В отца вся, шея от Юноны, голова Цереры, золотая. <...> а лицо - от Леонардо что-то, «Бель Фероньер». Там - русское, неуловимо: и скромность, и скрытая задорность взгляда. Идет неслышно, но сила с л ы ш и т с я . <..> Глаза!.. < ..> Под сердцем, в самой подоплеке у меня сказало: россыпи у ней, в с е - в глубине, в е с ь мир! <..> Я увидал глаза, с каким-то изумительным разрезом. Такие делают теперь иные, наводят негу, вызывают блеск и поволоку. Вот эта поволока, «думка» - от отца, с а м а рождалась. И вот, за ней-то, я угадал особенное, т о, чего ни у одной не встретил: живую беспредельность, целый мир! (ССШ; VII, 226).

Хотя по типу описания портрет напоминает предыдущий, но здесь видна попытка в портретном описании углубиться во внутренний мир героини. Паша напоминает «тип величавой славянки», которую описал Н. А. Некрасов в поэме «Мороз, красный нос»: «Есть женщины в русских селеньях / С спокойною важностью лиц, / С красивою силой в движеньях, / С походкой, со взглядом цариц»². Сказочные уподобления дополняются мифологическими (Юнона, Церера) и живописными («Бель Фероньер»), благодаря чему возникает некий собирательный образ идеальной героини. Важно, однако, что доминантой образа выступает «русскость» Паши.

Значимым для понимания образа Паши является постоянное сопутствие и опека отца, что вновь отвечает фольклорной традиции: «царевна не может быть изучена без ее отца» [4, 298]. Ряд сказочных персонажей продолжают остальные жители городка:

Старик какой-то, бородище по колени, голубая. Сам Синеус, ей-Богу! <...> Древняя старушка похрамывает по навозцу палкой. $<\ldots>$ Где-нибудь и мамка со шлыком (ССШ; VII, 224-226). 
А дом Разгуляевых, «вышний», стоящий «особо», с хрусталями на стенничках напоминает сказочный дворец.

В образе города можно обнаружить черты «тридесятого государства». Он географически обозначен как Белозерск, однако существует в сказочном времени и пространстве. Мотивы золота и солнца, вводимые при описании города, подтверждают это. По наблюдениям В. Я. Проппа, «все, сколько-нибудь связанное с тридесятым государством, может принимать золотую окраску. <..> Золото фигурирует так часто, так ярко, в таких разнообразных формах, что можно с полным правом назвать это тридесятое царство золотым царством» [4, 284-285]. В свою очередь, эпитет «золотой» является синонимом огненности, света. Если в «Неупиваемой Чаше» мотив света вводится описанием белых одежд барыни, то здесь эту функцию выполняет золотой цвет. Поэтому золотая окраска предметов выражает их солнечность и включенность в извечный временной цикл:

Площадь вся золотая, от навоза. <...> Стою на площади - Caхара, золото сухое, <...> Из-за бугров желтеет, соляные склады, времен Бориса Годунова, - <..> Сухие судачки висят на солние, белеют солью. <..> Ну, Пропалуйск, и только. Вспомнил Сан-Франциско, Нью-Йорк, Париж.. - сон, марево? И этот Белозерск, тысячелетнее, гнездище, - сказка? (ССШ; VII, 224)

Город становится воплощением невидимого «иного царства», живущего по сказочным законам и не связанного с внешним миром. В нем собраны одновременно осколки разных эпох, сказочные герои. Хота в рассказе нет икон, но сказочный хронотоп, где словно остановилось время и неопределимо пространство, напоминает особую форму иконичности - эонотопос, «в котором происходит сращение пространственно-временной модели с категорией вечности» $[7,8]$. Так, маленький городок становится сакральным топосом, образом рая. Ведь Кадырин блаженно чувствовал себя только здесь, в отличие от путешествий по заморским землям.

Сказочность Паши подчеркивает в ней и верность, и цельность, и исключительность, столь близкие русскому народному идеалу. Чувствуя указания провидения («Судьба толкнула: 
не мотайся! Вот, в Белозерске где-то, в глушине, - т е бе , родная... в с е - в ней!..» [CСШ; VII, 228]), Кадырин «смолчал», предпочтя свободу и «экзотику». Сравнивая Пашу с Татьяной Лариной, герой воспроизводит пушкинскую ситуацию. Кадырин, как некогда Евгений Онегин, увидевший в Татьяне Лариной будущую верную супругу и добродетельную мать, пренебрег своим счастьем.

Только вторая встреча с Пашей - певицей Линой-де-Келетти, звездой из Вальпараисо, - позволяет герою окончательно рассмотреть самобытность и глубину «девочки из Белозерска» (опять же акцентуация детскости), понять цену упущенного:

Ну, фурор! <...> Но, странно... слушаю... и - Белозерск! <...> Те с амы е глаза! <..> Те самые, - из моря. И голос - то т, грудной, из глубины... <..> И тут я понял, отчего все млеют, неистовствуют до истомы. Безмерность, беспредельность, глубина! <...> Паша... - международной стала! Мир-то, то т, в глазах!.. <...> И я, бродяга, плакал. В первый раз (ССШ; VII, 230-231).

Международное признание певицы не имеет ничего общего с типичной карьерой экстрадной звезды. Оно оказалось необходимо для Кадырина как утверждение и подтверждение не просто внешней красоты, а внутренней исключительности Паши. Встреча двух героев вновь напоминает сюжетную ситуацию из романа «Евгений Онегин»:

Вижу - Паша, из Белозерска Паша! Но - к а к а я! Царица, королева. Онемел. - А, здравствуйте. Читала про ваши подвиги. Ах, выходить мне... Здравствуйте и... до свиданья. Ах, да... зайдите к н а м.<..> А вот и муж мой... <..> Пошла. Пошел и я. Ну, как... Онегин и Татьяна. Хуже!.. Келетти, международная певица (ССШ; VII, 231).

Пушкинская ситуация констатирует не только настоящее, но и дальнейшее развитие ситуации. Ведь «белозерское», однажды бывшее в жизни людей, способно согреть и дальнейшую встречу, так напоминающую развязку романа в стихах. Поэтому образу Паши также присущ трагизм - несбывшаяся мечта об идеальной любви. Ведь через одиннадцать долгих лет она вновь безошибочно напевает шуточную телеграмму, 
посланную ей Кадыриным после отъезда из Белозерска. Онегинское просматривается и в типе личности Кадырина: герой предстает как «лишний человек» XX века, мучительно ищущий свое место в мире.

Похожее «трио»: «он», «она» и американец находится в центре неоконченного романа «Иностранец». Однако в романе именно американец, мистер Паркер, является тем третьим, который находит в певице под псевдонимом Таня Снежко другой мир - мир духовного света, родного, согревающего человеческую душу. Как и Кадырин, странноватый иностранец из Торонто способен оценить не просто красоту голоса и женскую привлекательность Ирины Хатунцевой, но увидеть исходящий свет и возродиться духовно. Мотивированные духовными причинами метания и поиски Эйба Паркера заканчиваются встречей с певицей Таней Снежко. Объясняя логику своих поисков и их цель, иностранец поднимается над земными рамками:

Я весь свет объехал, все бросил... а с в е т а так и не увидел. И вот где уж никак не ожидал, и - с в е т . В этом и главное, почему мне необходимо объясниться с вами (ССШ; VI, 468-469).

Намеченный в «Неупиваемой Чаше» и «Мареве» мотив света, сопровождающий героиню, здесь становится главным в характеристике Ирины.

Встретившись с Ириной, Паркер увидел возможность заполнить пустоту и обрести другой мир, мир, наполненный восхождением к Первообразному. Символом начинающегося духовного пробуждения иностранца становится его подарок Ирине - серебряное плато с чернью: орхидеи, гардении и незабудки, где посредине тонким золотом вырезано два слова - «Light in the Darkness», — «Свет во тьме».

Это объяснить и просто, и... непросто. Просто это - от вас мне с в е т . <..> Так я чувствую (ССШ; VI, 468).

Ирина же чутко слышит здесь евангельский текст:

Вспомнила, что это слова из первой главы Евангелия от Иоанна, которое читается на Пасху: «И с ве т во ть ме светит, и тьма не объяла его». <...> Для меня совершенно ясно, что тут не «излияния чувств», не я сама, а что-то пробудило в нем 
пение... не знаю. Во всяком случае, не ординарное, не пошлое (ССШ; VI, 448).

Эти евангельские строки читаются на Пасху как наиболее полно выражающие суть праздника (в Евангелиях есть описания самого события Воскресения, но ни одно из этих описаний не включено в пасхальное чтение). Архетип Пасхи намечает сюжетный и смысловой стержень романа - путь героя к духовному преображению (о пасхальности см. [2]).

Самое глубокое из евангелий - Иоанна Богослова в первых 17 стихах выражает суть личности Христа, «Слова» как источника света для окружающего мира: «Солнце правды, всем жизнь возсияюща». «Возсияюща»- это не только освещенная светом жизнь, но и зажженная этим светом, жизнь, которая становится сияющей. Именно это внутреннее сияние отражалось в пении Ирины, которое звучало чем-то родным для иностранца:

Передалось мне... чем-то, звуком вашего голоса, вашим... чувством... что вы можете все понять! <..> У меня и сейчас звучит в душе мотив, тот напев... как вы поете, про снега. <...> Все снега, снега, и... <..> не перейти эти снега, не пройти через них... к р одн о м у! <...> (ССШ; VI, 466-467).

В характеристике самой Ирины переплетаются разные виды интертекста различных эпох. Как и в описании Паши Разгуляевой, Шмелев очень мало говорит о внешней красоте. Перед читателем предстает лишь силуэт, увиденный как бы внутренним зрением, своеобразный внутренний портрет, представляющий незаурядную личность. Красота для Шмелева - это неотъемлемая черта идеального женского типа:

...античная Венера перед т о й - глыба, и больше ничего. <...> Манеры, линии... <..> глаза-а...(ССШ; VI, 436).

Все любимые героини Шмелева - красавицы. Но их внешность автор никогда не воссоздает детально, поскольку его интересует духовный облик. В этом Шмелев принципиально не следует ни Пушкину, ни Тургеневу. Писатель любил жизнь во всех ее проявлениях, поэтому идеальная, «шмелевская девушка» представлялась ему обязательно красивой. 
Если Паша была похожа на царевну, то Таня Снежко напоминает принцессу: «Может, и из принцесс» (ССШ; VI, 429); «будто из лучшего фарфора» (ССШ; VI, 442). В обоих случаях сравнение призвано подчеркнуть возвышенность и чистоту, которые покоряют окружающих.

Солистка русского хора Боярского, облеченная в любимый ее образ - «боярышни» - не оставляет равнодушным и Жюстина, способного уловить в пении хора русскую ментальность и почувствовать лежащую в ее основе христианскую духовность. Ведь пение хора, как и изображения на каноничных иконах, лишенное чувственности, телесности, движения, настраивает на восприятие духовного смысла и рождает гораздо более глубокий отклик, чем легко забывающееся эмоциональное представление. Ирина в «коконе», стоящая неподвижно, напоминает иконное изображение:

Выйдет ихний хор - ослепнешь. Это но-мер. Или певица, соло, в этакой... как это у них?.. не шляпка, а... кокон. Икона, стиль... иде-я. <...>. Стоит - как изваяние, как... ассирийская богиня (СCШ; VI, 435).

Но статичность облика, как и аскетичное иконное изображение, парадоксальным образом создает ощущение движения:

Ни пальчиком, а... все косточки у ней играют. Это - стиль (ССШ; VI, 435).

Если статичный лик иконы одухотворяется глазами, то здесь в невидимый мир увлекает пение, сообщающее благодать.

Этот образ угадал и детский учитель пения Ирины:

Татьяну пела ничего. Ярославну лучше, но когда он начал со мной мученье над Февронией из «Китежа», на третьем уроке поцеловал меня и сказал — «вот, это уж т в о е (ССШ; VI, 446).

Сравнение с девой Февронией из «Сказания о невидимом граде Китеже и деве Февронии» с одной стороны, отсылает к житийному и фольклорному типу героинь, а с другой позволяет увидеть сходство сюжетных коллизий. Ведь Ирину с ее мужем Виктором, как и Февронию с ее суженым, постоянно пытаются разлучить. Вынужденная бедностью 
жизнь порознь, нечастые встречи, постоянные поклонники певицы препятствуют безоблачному счастью супругов. Несмотря на это, она, как и Феврония, хранит верность любимому Виктору. Опять же акцентируется и жертвенность Ирины, ведь она не мыслит покинуть больного, но горячо любимого мужа-офицера, отбрасывая предоставляющиеся возможности более легких жизненных путей. Несмотря на серьезность жизненных коллизий, Ирина опять же не выглядит певицей из кабаре. Она пробуждает в иностранце частью отеческие чувства:

Вам я посылал цветы, как посылал бы дочери... от искреннего сердца (ССШ; VI, 465).

Лучшие качества героини подчеркиваются характеристикой «отыскавшаяся Мисюсь». Комментируя значение чеховского образа в романе Шмелева, Е. Куликова справедливо видит в этой отсылке попытку продолжить чеховский текст («Маленькая Мисюсь нашлась») и новую его интерпретацию [3; 420]. Как видим, главными в образе идеальной героини Шмелева становятся душевный свет и связь с национальными корнями, позволяющие даже людям других наций и культур почувствовать родное и подлинное, приобщиться к истинному. Недаром мотив света стал центральным и в описании О. Бредиус-Субботиной, оказавшейся идеальной героиней биографического сюжета Шмелева:

Ты дитя Света, Оля... - и такой останься, всегда такой пребудь... <..> Не могу я жить без Света, ты мне Свет. <...> Так вот, все ждал - войдешь, станешь рядом, и я... - и я вспоминаю «Свете тихий» (БШ, 442, 460, 589).

В мире Шмелева именно женское начало порождает небесную любовь и открывает путь к вечному блаженству.

Примыкает к шмелевскому типу и Катюша Вышгородская, пытающаяся неудачи любви заглушить шумихой шоу-бизнеса. Няня и Катичка не теряют связи с национальным, московским даже на чужбине, и это позволяет им сохранить свое «я», свою духовную сущность. Дарья Степановна даже во внешнем облике остается верна себе - носит платочек 
и наколочку, а Катя в суете киноиндустрии и различных шоу, исполненных соблазнов для красивой девушки,

...какая была, такая и осталась, как хрусталик чистый... ягодка свеженькая, без поминки (ССШ; III, 170).

Помогают сохранить чистоту не только прочные моральные ориентиры, но и никуда не ушедшая любовь к Васе Коврову. Убедившись в искренности любимого человека, Катичка решает соединить с ним жизнь. Этот образ среди других женских персонажей Шмелева выделяют горделивость и отчасти высокомерие девушки-дворянки, измучившей сердце юноши. Но все же в Кате, безусловно, пленяет высота и сила чувств, несогласие на обман в любви и преданность, столь редкая для молодой красавицы. Поэтому многолетние одинокие скитания по свету - это также жертва, на которую способны только сильные натуры. Как положительные женские типы, образы няни и Катички, на наш взгляд, восходят к пушкинским Татьяне Лариной и ее няне из «Евгения Онегина», воплощавшим собой способность к безграничной любви и жертвенности. Хотя мировидение Кати нельзя назвать иконичным (что традиционно для шмелевского типа), но в романе представлена интересная трансформация этого принципа. Вспомним, что именно няню Катя называет «иконка моя», воплощает иконичное мирочувствие няня, сохраняющая Катичку во всех треволнениях земного бытия.

Одновременно завершением и апофеозом типа «шмелевской девушки» стала Даринька, любимый образ писателя.

В изображении Дари Шмелев продолжил и развил основные черты своего женского типа: детскость, просветленность небесным светом, исключительность, очарование, духовную чистоту и силу, софийность, иконичность мировидения, женственность и преданность, трагизм судьбы и бездетность. Простую белошвейку писатель волшебно претворяет в дворянку, праправнучку святителя. Создавая образ Дариньки, Шмелев ставил перед собой сложную задачу детального изображения внутреннего мира девушки: «Я должен раскрыть Дарью» (ИШ, 163). Поэтому в описаниях доминируют черты духовного облика. 
В первые дни знакомства с ней Вейденгаммер сразу же обращает внимание на её духовную красоту:

Передо мной была осветлённая, возносящая красота. Не красота... это грубое слово тут, а прелестная девичья чистота... юница, воистину непорочная. Большие, светлые, именно звездистые глаза... (ССШ; V, 40-41).

С чистотой сочетается детскость. Вейденгаммер очень часто сравнивает Дариньку с ребенком: «...ах, ты, ре-бе-нок милый!» (ССШ; V, 76-77).

Необыкновенной видит ее и кутёжник, «тёртый калач» Вагаев:

Вы особенная... вы не похожи ни на кого! <...> Но она необыкновенная. Она святая! Это он чувствует, видит в её глазах (ССШ; $\mathrm{V}, 153)$.

Даже известный обольститель, барон Ритлингер способен выделить девушку в толпе светских красавиц:

Она - пре - ле - стна <... ... я её сразу выделил (ССШ; V, 155).

Даринька согревает светом своей души встреченных ею на жизненном пути, буквально преображает мир вокруг себя. Вейденгаммер поклонился «исходившему от нее свету», им же затронут и преображен Вагаев, называют «светлой» свою госпожу жители Уютова. С концептом света связано определение Дариньки как преображенной, новой. Ведь православный праздник Преображения - это осияние, освящение, очищение благодатным светом человеческого естества. И Даринька, своей душой участвующая в Преображении, одаренная этим светом, оказывается сама источником света для окружающих.

Даринька становится носителем иконичного восприятия, напоминает окружающим о неземном:

В вас великий отсвет того мира, того небесного, предчувствуемого, о чем мечтает поэзия, что ищет философия, что знает одна религия... вы его драгоценный отблеск» <курсив автора. - E. К.> (ССШ; V, 258). 
Портретные характеристики девушки сведены до минимума, изображение автором Дариньки можно назвать иконописным:

В голубых клубах ладана <..> утончившееся лицо казалось иконным ликом, ожившим, очеловечившимся в восторженном моленьи. Не девушка, не юница, а... иная, преображенная, новая $<$ курсив автора. - Е. К.> (ССШ; V, 42).

Именно поэтому Дариньке как носительнице чистого, иконичного, мировидения автор доверяет напоминать другим героям и читателям о высоте Божественного призвания человека.

В «Путях небесных» время, выводящее в вечность, эксплицируется в образе Дариньки, которая, живя в земном пространстве и времени, часто

...пребывала в «уюте от земного», <..> в неизъяснимом своем н и ч т о . Она не умела определить, говорила восторженно «будто не на земле... какое-то н и к а к о е, совсем пустое!» Пустое - конечно, в нашем, земном, определении <разрядка автора. - Е. К.> (ССШ; V, 227-228).

Пространство и время «нездешнего» мира Дариньки не очерчивается какими-то определенными категориями, раздвигаются пространственные и временные пласты, формируется пространственно-временная лакуна - эонотопос.

В «Путях небесных» ощущается влияние эстетики Вл. Соловьева и символистской поэзии. Так, обоготворение героини, сквозящее в письмах Вагаева из Петербурга, манифестирует Дари как Вечную женственность, актуализируя кодовую функцию мифа:

Вы Пречистая для меня... жена моя, вечная моя... чудесная, чудотворная, небесный ангел (ССШ; V, 252-253).

Между тем Шмелев смог показать и страстность Дариньки, проявившуюся в увлечении Вагаевым, и раскрыть перед читателем весь сложный рисунок душевных треволнений девушки. То, что внешними штрихами было намечено в Анастасии, в Дариньке развернулось в неповторимый портрет души. 
Поэтому разворачивающаяся лента женских типов от Анастасии до Дариньки воплощает собой уникальный женский тип - «шмелевской девушки», той, которая встречается лишь однажды, чистой и просветленной, женщины-принцессы, женщины-дитя, женщины-девы, наделенной иконичным мировидением, необычайно обаятельной, женственной (воплощающей софийное начало) и в то же время сильной, преданной своим высоким духовным идеалам и способной преодолеть трагизм и испытания собственной судьбы.

\section{Примечания}

1 Цитаты приводятся с использованием следующих сокращений: БШ - И. С. Шмелев и О. А. Бредиус-Субботина: Роман в письмах: В 2 т. Т. 1. 1939-1942 / Предисл., подг. текста и коммент. О. В. Лексиной, С. А. Мартьяновой, Л. В. Хачатурян. М.: Российская политическая энциклопедия (РОССПЭН), 2003. 760 с.

ИШ - Шмелев И. С. Переписка двух Иванов: В 3 т. Т. 1. Переписка двух Иванов 1927-1934 / Сост., вступ. ст., коммент. Ю. Т. Лисицы. М.: Русская книга, 2000. 560 c.

ССШ - Шмелев И. С. Собр. соч.: В 5 т. / Подгот. текста, вступ. ст. Е. А. Осьмининой. М.: Русская книга : Известия, 2004.

2 Некрасов Н. А. Собр. соч.: В 8 т. Т. 2. Стихотворения и поэмы 18611877 / Под. ред. К. И. Чуковского. М: Худож. лит, 1965. С. 86.

\section{Список литературы}

1. Дзыга Я. О. Типология женских образов в творчестве И. С. Шмелева // Русская литература за рубежом. М., 2007. С. 65-83.

2. Есаулов И. А. Пасхальность русской словесности. М.: Кругъ, 2004. $560 \mathrm{c.}$

3. Куликова Е. Г. «Light in the darkness»: Чехов глазами Шмелева // Moлодые исследователи Чехова: Материалы междунар. науч. конф., (Москва, 14-18 мая 2001 г.) / МГУ им. М. В. Ломоносова. М., 2001. C. $417-426$.

4. Пропп В. Я. Исторические корни волшебной сказки. Л.: ЛГУ им. А. А. Жданова, 1986.366 с.

5. Руднева Е. Г. Диалог традиций в повести И. С. Шмелева «Неупиваемая Чаша». М.: МАКС Пресс, 2007. 64 c.

6. Трубеиякой Е. «Иное царство» и его искатели в русской народной сказке // Литературная учеба. 1990. Кн. 2. С. 101-118. 
7. Шкуропат М. Ю. Иконичность художественного образа (на материале произведений И. С. Шмелева): автореф. дис. ... канд. филолог. наук. Донецк: ДНУ, 2007. 20 с.

\title{
Evgeniya Alexandrovna Korshunova
}

Ph.D. in Philology, the Senior Lecturer of the Department of History of Russian Literature,

Vasyl Karazin Kharkiv National University, (Kharkiv, Ukraine)

zhenyakorshunova@gmail.com

\section{"DARI-ANASTASIA-OLGA-THE RESURRECTED": THE IMAGE OF "IVAN SHMELEV'S GIRL"}

\begin{abstract}
The attempts to build the typology of Shmelev's female images have been repeatedly made by researchers. However, we think that the author in his works and correspondence, relying on classic literature and questioning it at the same time, shapes his own whole unity, and his own unique female character - the 'Shmelev's girl'. So, the analysis of the poetics of several Shmelev's works (The Inexhaustible Cup, Mirage, A Foreigner, Nanny from Moscow and Heaven's Ways) using comparative, historical and inter-textual methods reveals their close interrelationship.

The gallery of women's characters - from Anastasia to Darinka - represents the unique type of a woman - the so-called 'Shmelev's girl', who, is on the one hand a pure and enlightened princess, a baby and a maiden, pure, enlightened, with iconic world perception, extraordinary charming and feminine (sophistic), but, on the other hand, very powerful, totally devoted to her high spiritual ideals and capable of overcoming tragedies and trials of her own destiny.
\end{abstract}

Keywords: a type, tradition, Shmelyov's girl, iconicity, sophism

\section{References}

1. Dzyga Ya. O. Tipologiya zhenskikh obrazov v tvorchestve I. S. Shmeleva [Typology of Female Images in Ivan Shmelev's Works]. Russkaya literatura za rubezhom [Russian Literature Abroad]. Moscow, 2007, pp. 65-83.

2. Esaulov I. A. Paskhalnost' russkoy slovesnosti [An Easter Orientation of Russian Literature]. Moscow, Krug Publ., 2004. 560 p.

3. Kulikova E. G. «Svet vo t'me»: Chekhov glazami Shmeleva [«Light in the Darkness»: Anton Chekhov Through the Eyes of Ivan Shmelev]. Molodye issledovateli Chekhova: Materialy mezhdunar. nauch. konf. (Moskva, 14-18 maya 2001 g.) [Chekhov's Young Researchers: Materials of the International Scientific Conference (Moscow, 14-18 may 2001)]. Moscow, 2001, pp. 417-426. 
4. Propp V. Ya. Istoricheskie korni volshebnoy skazki [Historical Roots of the Fairy-Tale]. Leningrad, Leningrad State University named after A. A. Zhdanov Publ., 1986. 366 p.

5. Rudneva E. G. Dialog traditsiy v povesti I. S. Smeleva «Neupivaemaya Chasha» [Dialogue Between Traditions in Ivan Shmelev's Short Novel "The Inexhaustible Cup"]. Moscow, MAKS Press Publ., 2007. 64 p.

6. Trubetskoy E. «Inoe tsarstvo» i ego iskateli v russkoy narodnoy skazke ["Alien Kingdom" and Its Seekers in the Russian Folk Tale]. Literaturnaya ucheba [Literary Studies], 1990, no. 2, pp. 101-118.

7. Shkuropat M. Yu. Ikonichnost' khudozhestvennogo obraza (na materiale proizvedeniy I. S. Shmeleva). Avtoref. dis.... kand. filolog. nauk [Iconicity of an Artistic Image (based on Ivan Shmelev's works). PhD. philol. sci. diss. abstract]. Donetsk, Dnipropetrovsk national university Publ., 2007. 20 p. 